\title{
The Analysis of the Pattern of Aquaculture Business Management Application to Increase the Farmers' Income in Pangkep Regency
}

\author{
Sumarni, \\ Lecturers of Fishery and Agribusiness of State Polytechnic of Pangkep \\ Mariam, \\ Lecturers of Fishery and Agribusiness of State Polytechnic of Pangkep \\ Hadija
}

The Maros Educational Foundation

Received: February 27, 2017

Accepted: June 12, 2017 Published: June 29, 2017

doi:10.5296/jas.v5i2.11472

URL: https://doi.org/10.5296/jas.v5i2.11472 


\begin{abstract}
The study focuses on the intensification by applying processing technologies of ponds through the programs of pond intensification, which is the farming techniques, covering the repair of pond construction, water, pest/disease control, fertilization and supplementary feeding, stocking of high quality seeds, processing, marketing and business management. Extensification is intended to expand the fish farming to several areas that have great potential, while diversification is directed at the diversity of the fishery as well as the development of processing and marketing industry. This study was conducted in Pangkep Regency, Pangkajene Distrcit, Bungoro, Labakkang, Ma'rang 'and Segeri, Mandalle since this area is one of the development areas for pond intensification in South Sulawesi. This activity was carried out by field observation through interviews, questionnaires and focus group disscussion with all relevant parties. This research used qualitative and quantitative analysis methods by which data and information obtained were analyzed quantitatively and then qualitatively by using a multiple regression analysis.
\end{abstract}

Keywords: Intensification, Pond, Management, Farming

\title{
1. Introduction
}

While intensive farming seems to be relatively easy to do, in its implementation a lot of farmers including the researchers face various problems and obstacles and the solutions for them are also difficult to find.

Environmental problems in the shrimp ponds are greatly associated with the site selection process which is not carried out with care as well as the inapporpriate business management e.g., water quality management, feeding and lack of coordination among farmers. Another problem in the cultivation is the problem of capital involving huge costs to build a new pond complete with secondary and tertiary canals. Besides, working capital for the purchase of seeds for farmers with small capital can be a serious problem. Farmers often face a problem of bank lending, such as collateral and business feasibility. Production issues concerning feeding, fertilizers, pesticides are related to poor time management. The quality of the number and the price of production facilities are fluctuative, hampering the sustainability of production.

Intensification is done by applying processing technologies of ponds through the programs of pond intensification, which is the farming techniques, covering the repair of pond construction, water, pest/disease control, fertilization and supplementary feeding, stocking of high quality seeds, processing, marketing and business management.

The focus of this research is on the pattern of aquaculture business management application, covering the repair of pond construction, water, pest/disease control, fertilization and supplementary feeding, stocking of high quality seeds, processing, marketing and business management as well as how big their influence is to the increase of farmers' income.

\section{Research Methods}

This study was conducted in Pangkep Regency, South Sulawesi. In the first year, a field study 
was carried out to determine the pattern of agricultural business management application. This activity was carried out by field observation through interviews, questionnaires and focus group disscussion with all relevant parties.

The analytical method used in this study are:

1. A description of this study is the result of research that explains the analysis of increasing farmers' income through the application pattern of aquaculture business management application according to the responses of farmer respondents as the feasibility of respondents in providing information to the questions given in the questionnaire posed based on the understanding level of the respondents. The $\mathrm{X}$ variable as the independent variable consists of the construction of ponds, provision / setting, tillage, seeds, pests and diseases, processing and business management. The dependent variable $(\mathrm{Y})$ is the income levels of farmers.

2. The method of multiple regression analysis

3. Regression analysis was used to determine the relationship between several independent variables (X) and their dependants (Y). The analysis of the data here has the ultimate goal to test the research hypothesis about how much influence the business management has to increase farmers' income. The regression model to test the hypothesis in this study used the linear regression model (Sudjana, 1992: 312) as follows:

$$
\text { i. } \mathrm{Y}=\mathrm{bo}+\mathrm{b} 1 \times 1+\mathrm{b} 2 \mathrm{X} 2+\mathrm{b} 3 \mathrm{X} 3+\mathrm{b} 4 \mathrm{X} 4+\mathrm{b} 5 \mathrm{X} 5+\mathrm{b} 6 \mathrm{X} 6+\mathrm{b} 7 \mathrm{X} 7+\mathrm{ei}
$$

Note:
ii. Y: Increased Revenue
iii. X1: Construction of ponds
iv. X2: Supply and Water regulation
v. X3: Management, fertilization and feeding
vi. X4: High qualityseeds
vii. X5: Pests and diseases
viii. X2: Processing and marketing of the products
ix. X3: Management of business
x. b1-b7: Coefficient regression (parameter)
xi. bo: Constants (Intercept)
xii. ei: error factor

1. The level of income (Y) is the final value of aquaculture revenue earned after deducting the costs of aquaculture practices.

2. Construction of ponds (XI) is the pattern of the aquaculture businesses management application, which is a pond that is used to manage the aquaculture businesses physically and construction technically, covering the manufacture / repair, locks, aqueducts, and the layout of the farm.

3. Provision of water regulation (X2) is the pattern of the aquaculture businesses that determines success in aquaculture through the management of water media. 
4. The management of soil, fertilization and feeding (X3) is the activities performed in the application of organic and inorganic fertilizers both in the pond preparation and after pond maintenance; meanwhile feeding is applied to accelerate growth.

5. Quality seeds (X4) is the mastery of cultivation techniques in seed husbandry

6. Pests and diseases (X5) is an attempt to remove the pests and diseases that are still alive despite the ponds have been dried.

7. Marketing processing products (X6) is the handling and processing as well as quality maintainance to gain a decent price.

11. Business Management (X7) is the pattern of the aquaculture business management application engaged in a process of production and management done by the farmers themselves.

\section{Results And Discussion}

Based on the respondent characteristics and description of the variables above, the data were processed through linear regression equation with the help of SPSS10.0 program, and then the printout formulated in equation was gained, as shown in Table 1:

Table 1. Multiple Linear Regression Calculation Results

\begin{tabular}{|l|l|}
\hline \multicolumn{1}{|c|}{ Variablel } & \multicolumn{1}{c|}{ Regression } \\
\hline Constants (Revenue) & $\mathrm{B}_{0}=1250927,2$ \\
Pond construction & $\mathrm{B}_{1}=5624617,9$ \\
Provision / Settings & $\mathrm{B}_{2}=1376330,5$ \\
Land management & $\mathrm{B}_{3}=2031989,1$ \\
High Quality seeds & $\mathrm{B}_{4}=1420117,8$ \\
Pests & $\mathrm{B}_{5}=1275995,0$ \\
Management of products & $\mathrm{B}_{6}=1014989,7$ \\
Business Management & $\mathrm{B}_{7}=1656773,4$ \\
\hline
\end{tabular}

\subsection{Test $-F$}

F-Test of the confidence level was at $95 \%$ statictically showing that the seven independent variables, simultaneously, had a very significant influence on the increase of farmers' income, because the evel of significance was 0.05 . The details can be seen in Table 2 below:

Table 2. Calculation Results of ANOVA (Test-F)

\begin{tabular}{|l|l|r|r|r|r|r|}
\hline \multicolumn{2}{|c|}{ Model } & Sum of Squares & Df & Mean Square & F & Sig. \\
\hline $1 \quad$ & Regression & 66.895 & 7 & 9.556 & 41.035 & \\
\cline { 2 - 8 } & Residual & 9.781 & 42 & .233 & & \\
\cline { 2 - 7 } & Total & 76.676 & 49 & & & \\
\hline
\end{tabular}




\section{Macrothink}

Based on Table 10 above, it is known that the F-count is greater than the f-table which is 41,035 4.9646. This means that overall the studied independent variables has a sinificant influence on the dependent variables.

\subsection{Test- $t$}

T- test was determined by $95 \%$ confidence, statistically showing that the t-test of each of the independent variables had a significant impact. If the $\mathrm{t}$ count $\mathrm{t}$-table then it was said to be significant with a probability p 0:05. More details are shown in Table 3 as follows:

Table 3. Student's test result (t-test)

\begin{tabular}{|l|r|r|c|}
\hline \multicolumn{1}{|c|}{ Variable } & t-test & & Note \\
\hline Construction of ponds & 15,907 & 0.000 & Significant \\
Provision/regulator & 0,231 & 0,819 & Significant \\
Management of Land & 0,311 & 0.757 & Significant \\
High quality seeds & 0,550 & 0,586 & Significant \\
Pests & 1,807 & 0,078 & Significant \\
Management of products & 0.616 & 0,541 & Significant \\
Business management & 0,732 & 0,468 & Significant \\
t-table = 1.7613 & & & \\
Significance Level $\alpha$ 5\% $=0,05$ & & & \\
\hline
\end{tabular}

Based on Table 11 above, the dominant variable is the motivation and the non-dominant variable is the work environment. Each of these studied variables influence significantly the probability significantly with probability (p) of 0.05 except for the work environment variable that indicate the probability $(\mathrm{p})$ of 0:05.

\section{$1.3 R$ Square}

$\mathrm{R}$ Squared or determination coefficient was at 0.934, meaning that the contribution of the seven variable $\mathrm{X}$ to variable $\mathrm{Y}$ was equal to $93.4 \%$ or in other words there was a strong influence of independent variables on the dependent variable. More details can be seen in Table 4 on the results of the calculation of R Square as follows:

1. Effects of pond construction (X1) to the income level. 


\section{Macrothink}

Journal of Agricultural Studies

ISSN 2166-0379

2017, Vol. 5, No. 2

The construction of ponds is the technical factor that includes manufacture / repair of embankments, floodgates, canals and ponds layout.

a) Embankment

The main embankment is an embankment that surrounds the pond unit (the whole pond). The main embankment serves to maintain the water level in the pond units, hold flood water at the highest tide of the flood water, and act as a pond ownership border.

The main embankment is an embankment that surrounds the pond unit (the whole pond). The size of the main embankment is as follows:

1. The height of at least $50 \mathrm{~cm}$ above the surface of water at high tide.

2. The width of the top $2-2.5$ meters or more.

3. Comparison of high side slope breadth (talud width) is $1: 1.5$ with its dimension inside 1: 1

4. The width of the berm (ladders bund) 0.5 to 1 meter

b) Floodgate

There are 2 types of floodgates required in each unit of the pond, which are the main floodgate placed in front of the main plot (channel) of water divisor, and several plots doors installed between the embankments, according to the number of existing plots.

c) Drains

Table 4. The comparitheson of main channel to the tides

\begin{tabular}{|llr|}
\hline $\begin{array}{l}\text { Differences of tide } \\
\text { of main } \\
(\mathrm{Ha})\end{array}$ & \multicolumn{1}{c}{ Width } & $\begin{array}{r}\text { Width } \\
(\mathrm{m})\end{array}$ \\
\hline 7 & $\leq 1,5$ & $\leq 20$ \\
8 & & $>20$ \\
5 & $>1,5$ & $\leq 20$ \\
6 & & $>20$ \\
\hline
\end{tabular}

d) The moat (Caren)

One of the functions of caren is the shelter for fish or shrimp from pests and sun. The size of the moat is 3-4 m wide with a depth of 0.8 to $1 \mathrm{~m}$ from the court; has its bottom of $15 \mathrm{~cm}$ above the basic plot of the catching or between the embankments.

e) The layout of pond 


\section{Macrothink}

Journal of Agricultural Studies

ISSN 2166-0379

2017, Vol. 5, No. 2

Each embankment should have several plots, consisting of seeds plots, breeding plots of 1: 9: 90 respectively. Fish farming, particularly, does not use seeds spreading, so the ratio of seeding and breeding plots is 1-9.

2. Effect of the supply / regulation of water (X2) on the level of income

One of the key determinants of success in aquaculture is the management of water conservancy media. Water management is an activity that includes water intake, water output / turnover and water quality.

\section{a). Water Availability}

Before the entry of water into the pond, pond preparation was fist conducted by, among others, drying the bottom soil of the pond. Drying is done by removing the water in the ponds and then let the bottom dried up until it is cracked, yet not dusty. Drying aims to:

\section{Mineralize organic materials in the pond}

2. Eliminate toxic gases such as $\mathrm{H} 2 \mathrm{~S}, \mathrm{CH} 4$ and $\mathrm{NH} 3$ resulting from the decay process when ponds contain water

3. Kill pests and parasites

4. Lower the acidity of the soil in preparation for the management of ponds

b). Water quality

The effort to maintain water quality in the ponds is a process / activity of water intake and output from and into the pond, either through a floodgate or by arrin siphon. Besides, water quality can be maintained for example with the aid of aeration in the form of a blower or wheel (paddle whell) . The aeration is particularly necessary in the intensive shrip cultivation. Because shrimps require a lot of oxygen, especially at night, then aerasion to the pond area of $2.5000 \mathrm{~m}^{2}$ and a water depth of 1.0 meters with the stocking of shrimp $150 / \mathrm{m}^{2}$ was given in the form of 2 windmills aeration each day with the power of each 2 horsepower (HP).

1. Effect of soil management, fertilization and feeding (X3) on the level of income

Fertilization is an activity that is done by giving organic or inorganic fertilizers both in the pond preparation and maintenance. Menwhile, supporting food was aimed at fish or shrimp cultivated temporarily in the pond in order to accelerate its growth.

a. Fertilization

Fertilization in ponds aimed to make the natural food (klekap, algae and phytoplankton) could flourish so fish / shrimp could grow faster and pond production could be as optimal as possible.

\section{b. Basic Fertilization}

Basic fertilization was performed at the pond in preparation, which was when the court of the pond had been processed or had had enough drying / land has been basically cracked . 


\section{Macrothink}

Fertilizers used were organic fertilizers, either from animal manure, green manure or fine bran and coconut cake.

\section{c. Fertilization aftershocks}

To ensure the sustainability of klekap (natural food) growth during maintenance, it is necessary to do fertilization aftershocks. The fertilizers used was inorganic, generally those containing arrin $\mathrm{P}$ and $\mathrm{N}$ such as TSP and urea dosage adjusted based on the needs. As a guideline, urea was $10-25 \mathrm{~kg} / \mathrm{ha}$, or TSP $8-15 \mathrm{~kg} /$ ha or vice versa.

\section{d. Supplementary feeding}

Feeding was given mainly to the shrimp when the natural food in the ponds was estimated to be less, which was about 30-40 days after stocking of seedlings in Table 5.

Table 5. Relationship of shrimp weight with the amount of feed per day

\begin{tabular}{|l|c|}
\hline Total Weight of Shrimp Body (gr) & The amount of feed given per day (\%) \\
\hline $1-10$ & 25 \\
$11-15$ & 10 \\
$16-20$ & 8 \\
$21-25$ & 6 \\
$26-$ harvest (3,5-4 months) & 4 \\
\hline
\end{tabular}

2. Influence of high quality seeds (X4) on the level of income

The success of aquaculture is specified by the knowledge of cultivation techniques as well as is determined by the utilization of the seed. Cultivation of seeds includes seed supply done continuously and fairly in a timely manner.

a. Seed sources

Windu shrimp seed (Panaeus monodon) are obtained from the catching at sea and from the hatchery while the seeds of milkfish (Chanos-Chanos) is only obtained from capture at sea.

Seeds from hatchery have the same relative size, do not depend on the season or climate and its freshness is guaranteed while fry and milkfish are caught from the sea is mixed with other shrimp / fish. Thus the milkfish fry tiger arri please note the following features:

3. The seeds of windu shrimp

a. The total length of $1-2 \mathrm{~cm}$, dark brown body color from the tip of the tail to the base of the low tide.

b. Eye Stalk tapered form an angle of $+30^{\circ}$

c. straight elongated body shape resembles a piece of stick

d. tentacle in dappled vague color and rather rare.

e. In a state of rest, whiskers tend to lead down 


\section{Macrothink}

f.The tail end has brown spots spread evenly, increasingly darker inside.

g. Swimming irregularly, sometimes swimmping upright and love to dwell in the camp base or attached to the substrate.

4. The seeds of milkfish

a. The total length $1 / 3-2 \mathrm{~cm}$ with a clear brown color (transparent)

b. There are two points of a black eye on the head

c. In the middle of the body there is a point of white backs, as air bubbles

d. The anal fin is located behind the dorsal fin

e. Moving swiftly, swimming in a cluster on the surface of the water

\section{Seeds Transportation}

The layout of the ponds are usually far apart from the seed sources (marine and Hatchery), so that the transportation of seeds is necessary.

Seed density for the transport of milkfish is 1,000 head / liter of water and for fish is 500 head / liter of water. Meanwhile, for long distances taking 4 hours, a transport of closed system is necessary, which uses arring bags or cans filled with oxygen.

a. Environment adaptation.

b. Seed Shelter

c. The breeding

\section{Seeds Spreading}

Some things to consider before and at the time of seeding:

a. If the PL 30 shrimp seeds are harvested from a wooden tub, the seeds should be kept 1-3 days in the cage for the adjustment to the pond environment. But, if the shrimp seeds are harvested from the cage after PL 30, they are then able to be stocked into breeding plots.

b. Similarly, milkfish from concrete tanks should be adjusted first to the pond environment in a cage for1-3 days. But if they are ponds, they can can be directly transferred to breeding plots.

c. The seeds from the wooden tub or concrete tank before reared in cages are previously adjusted for the temperature and salinity of water.

d. PL 30 which are going to be spread in the beeding plots should be calculated, so that the productivity of the pond can be seen after the shrimp / milkfish are harvested.

e. Seed should be stocked in several places around the pond, so penyebaranya average and less food competition occurs. 


\section{Macrothink}

Journal of Agricultural Studies

ISSN 2166-0379

2017, Vol. 5, No. 2

f. At the time of container deployment (basin), the seed container is tilted slowly into the water and the seeds are left on their own.

g. seeds spreading should be done in the morning or late afternoon to avoid the high temperature fluctuations.

h. Density for semi-intensive maintenance.

While the stocking density in intensive care is using INTAM pattern

i. A program tambak intensification (INTAM A), stocking density measurement.

j. k) The pattern mix of shrimp and fish (INTAM B), solid batches of PL 30 A are 20,000 fish / ha with 5,000 spindles head / ha.

1) after 3-4 months of maintenance, an expected production using INTAM pattern is $800 \mathrm{~kg} /$ ha / growing season for INTAM A or 400 kgudang with $250 \mathrm{~kg}$ milk / ha / planting season for INTAM B.

a. Effect of Pests and Diseases (X5) on the Income Level

Control / eradication of pests is an attempt to remove the pest which is still alive despite the fact that the ponds have been dried. Pests is the kind of animals that are disturbing, contendering, attacking / injuring or eating (prey) or environmentally damaging shrimps and fish reared in ponds.

Some common types of pests in ponds are wild fish, snail trisipipan, crabs, snakes, leafhoppers, and fish-eating birds.

The types of shrimp diseases that often arise due to environmental influences, among others, are:

a. ill disease

This disease is often found in ponds rarely having a water change. The disease is caused by Detritus due to the murky and thick mud base, so it often sticks to the gills of shrimp. The prevention for this is by conducting regular water changes and dredging the thick bottom mud in the circumference.

\section{b. Muscle Necrosis}

Inin disease is caused by a combination of high temperatures and low oxygen levels, so the white streak colors appears on the tail and eventually become entirely white because of damaged tissue. The prevention is by doing regular water changes.

c. Porous body

Porous body is marked if the prawns were mushy, have thin skin on the body and there are air cavities between the skin and muscle tissue. The causes for this are the lack of food and poor pond condition. The control for this disease is by improving the condition of the pond and giving suffcient feeding for 7-10 days. 
a. Effects of refineries and product marketing (X6) on the level of income

Handling and processing shrimp or milkfish aims to maintain the quality for the consumers. Meanwhile, the marketing of products is made with the aim of getting a fair price.

e. handling results

Handling shrimp or milkfish should be done from the catch in pond to the hands of the consumers. This is done to reduce or slow down the deterioration of shrimp or milkfish captured from the pond.

f. processing of the products

Processing of the ponds can be done by means of traditional and modern methods. Besides being consumed, Milkfish is also marketed in the form of fresh or processed first. The processing which is often carried out on milkfish is still limited to traditional processing, which aare fogging and frying. Meanwhile, shrimp is for consumption and for export and its processing has been modern e.g .,the freezing of shrimp in cold storage.

g. marketing of the products

The marketing of the products for getting a fair price is determined by the plan and the management of ponds to harvest. It is also determined by the agency and marketing services. With the proper functioning of all Carrin, personnel or agencies and marketing provisions based on consumers demand, the efficinet marketing objectives will be achieved. The efficient marketing arises if all the institutions involved benefit in accordance with the services of issuance.

Thus, the farmers can determine the timeliness of harvest shrimp in the size desired. But it often occurs that during harvest the shrimp price drops. This is due to a lack of marketing agency formed by fish farmers themselves and teh existing market institutions are not functioning well.

b. Effect of Business Management (X7) on the Income Level.

To achieve the production and productivity of ponds as expected, then fish farmers are required to have knowledge of engineering as well as planning and business management.

1. Knowledge of techniques, including knowledge of aquaculture businesses.

2. Planning and management of business

3. The use of cost, include:

a. The investment costs, namely: repair the embankment, repair of equipment, manufacture of floodgates, equipment (gauges and harvest instruments) and the water pump.

b. Exploitation costs, namely: fish and shrimp seed purchases, purchases of fertilizer or feed, pesticide purchases, living expenses, depreciation of tools, fuel, maintenance pond, bank interest and so forth. 


\section{Macrothink}

4. Determination of the type of business

5. Loan or lines of credit and repayment

6. Additional knowledge that supports the implementation of the aquaculture businesses.

7. Selection of the appropriate means of production and the selection and the usage of appropriate equipment.

8. The use of manpower appropriately and properly.

9. Provision of decent living costs and adopting of the results to avoid too high fixed costs. The marketing knowledge of products, such as market information to get a fair selling price.

10. Application of proper harvesting methods to obtain the high exchange rate.

Harvest planning in accordance with the market demands, such as milkfish harvest which is done at the time of catching fish in the ocean experincing a decrease.

\section{Conclusions And Suggestions}

\subsection{Conclusions}

a. As overall, the increase in pond revenues was strongly influenced by the application of aquaculture business management.

c. The responses of fish farmers and the verification of results show that the construction of the pond is the application of management pattern. Aquaculture businesses greatly influenced the increase of farrmers' income in managing good aquaculture businesses either through the pond intensification or non pond intensification programs.

\subsection{Suggestions}

1. Being inputs for fish farmers and decision makers regarding the aquaculture sector in the Fisheries Department of Pangkep Regency to be further input and consideration about the increase in the income of farmers through a pattern of aquaculture business management application.

2. A pattern of aquaculture business management application is improved intensively to achieve the target of increasing farmers' income and welfare of the pond, so it is necessary to conduct a training or counseling on the implemantation and application of this pattern to all fish farmers.

3. Being a valuable reference for further research intending to examine other aspects of the application of aquacuture businesses to increase the income of aquaculture fish farmers in the form of another study. 


\section{References}

Ahmad, T, Ratnawati, E., \& dan Yakob, Jamil,. (2000). Budidaya Bandeng Secara Intensif, PT. Penebar Swadaya, Jakarta.

Anonim. (2001). Data Statistik Sektor Perikanan Dalam Angka. Dinas Perikanan Propinsi Sulawesi Selatan.

Anonim. (2000). Sapta Usaha Pertambakan, Dinas Perikanan Propinsi Sulawesi Selatan

Anonim. (1987). Rencana Intensifikasi Tambak (INTAM) dan Intensifikasi Ternak Kerja (INTEK) di Kabupaten Pangkep, Dinas Perikanan Kabupaten Pangkep.

Anonimous. (1985). Jurnal Penelitian Budidaya Pantai, Balai Penelitian Budidaya Pantai Maros, Ujung Pandang.

Arikunto, Suharsimi. (1999). Penemuan Sampel Penelitian. PT. Gramedia Pustaka, Jakarta.

Gaspersz. (1998). Manajemen Produltivitas Total. Penerbit Gramedia Pustaka Utama, Jakarta.

Hanafiah, A. M., \& dan Saefuddin A. M. (1986). Tataniaga Hasil Perikanan, Universitas Indonesia. Jakarta.

Haming. (1997). Manajemen Produktivitas. Penerbit Eka Persada, Jakarta.

Manulang, M.. (1981). Dasar-dasar Manajemen, Ghalia Indonesia, Jakarta.

Mardianto, Hadi. (2000). Budidaya Tambak. Penerbit Rineka Cipta, Jakarta.

Mubyarto. (1998). Pengantar Ekonomi Pertanian, LP3ES. Yogyakarta.

Naichochi. (1999). Fishing Cultivated, Fish Production Handbook.

Santoso, Sadik. (1997). Analisis Pendapatan Petani, Harvarindo, Jakarta.

Subantri, Sutopo. (2000). Budidaya Udang Windu, Liberty, Yogyakarta.

Sudjana. (1999). Metodologi Statistik Penelitian, PT. Gunung Agung, Jakarta.

Sudrajat, H. (2001), Budidaya Tambak dan Peternakan, PT. Raja Grafindo Persada, Jakarta.

Suyanto, S. R., dan Mujiman, A. (2001), Budidaya Udang Windu, PT. Penebar Swadaya, Jakarta.

Suyanto, Heru. (2000). Membuat Kolam Ikan, PT. Penebar Swadaya, Jakarta.

Soetomo, H, A. M. (1990). Tehnik Budidaya Udang Windu, Penerbit Sinar Baru, Bandung.

Sallatang, Arifin, M. (2001). Perubahan perilaku dan Cara Berpikir, Lephas, Ujung Pangdang.

Soehardjo, A., \& dan Dahlan Patong. (1978). Sendi-sendi Pokok Ilmu Usaha Tani, Lephas, Ujung Pandang. 


\section{Macrothink}

Journal of Agricultural Studies

ISSN 2166-0379 2017, Vol. 5, No. 2

Tahawilla, Amir. (1979). Kehidupan Sosial Ekonomi Petani Tambak, PLPIIS Unhas, Ujung Pandang.

\section{Copyright Disclaimer}

Copyright for this article is retained by the author(s), with first publication rights granted to the journal.

This is an open-access article distributed under the terms and conditions of the Creative Commons Attribution license (http://creativecommons.org/licenses/by/4.0/). 